\title{
Hubungan antara Kadar Seng dalam Serum dengan Fungsi Eksekutif pada Anak dengan Gangguan Pemusatan Perhatian dan Hiperaktivitas (GPPH)
}

\author{
Rivo Mario Warouw Lintuuran, Tjhin Wiguna, Nurmiati Amir, Agung Kusumawardhani \\ Departemen Psikiatri Fakultas Kedokteran Universitas Indonesia/Rumah Sakit Dr. Cipto Mangunkusumo, Jakarta
}

\begin{abstract}
Latar belakang. Belum ada hubungan yang jelas antara kadar seng serum dengan gangguan fungsi eksekutif pada anak dengan GPPH. Tujuan. Mengidentifikasi perbedaan rerata kadar seng dalam serum anak GPPH dengan gangguan dan tanpa gangguan fungsi eksekutif, anak non-GPPH, serta mendapatkan korelasi antara kadar seng dalam serum dengan fungsi eksekutif.

Metode. Penelitian potong-lintang yang disertai dengan kelompok kontrol. Dari dua sekolah dasar di Jakarta, secara acak diambil 90 anak sebagai subjek penelitian yang terbagi dalam 3 kelompok, yaitu anak GPPH dengan gangguan ( $n=30)$ dan tanpa gangguan ( $n=30)$ fungsi eksekutif, serta non-GPPH (n=30). Kadar seng serum diperiksa dengan metode ICP-MS di Laboratorium Prodia Jakarta. Fungsi eksekutif didapatkan melalui kuesioner BRIEF versi Bahasa Indonesia. Analisis data menggunakan SPPS for Windows versi 20.

Hasil. Dari seluruh subjek penelitian, 75\% mengalami defisiensi seng. Kadar seng tidak normal terdapat pada 60\% anak GPPH dengan gangguan fungsi eksekutif. Rerata serum seng pada kelompok anak GPPH dengan gangguan dan tanpa gangguan fungsi eksekutif, serta non-GPPH berturut-turut 59,40, 55,36, dan 52,93 $\mu \mathrm{g} / \mathrm{dL}$. Tidak dijumpai perbedaan rerata seng di antara tiga kelompok tersebut $(\mathrm{p}=0,119)$. Koefisien korelasi antara kadar seng serum dengan fungsi eksekutif adalah $\mathrm{r}=0,128$.

Kesimpulan. Kadar seng serum diduga tidak berhubungan secara langsung dengan gangguan fungsi eksekutif, tetapi lebih berhubungan dengan gejala klinis GPPH yang menyerupai beberapa gejala gangguan fungsi eksekutif. Sari Pediatri 2015;17(4):285-91.
\end{abstract}

Kata kunci: GPPH, seng serum, fungsi eksekutif

\section{Correlation between Serum Zinc Level and Executive Function in Children with Attention Deficit/Hyperactivity Disorder (ADHD)}

Rivo Mario Warouw Lintuuran, Tjhin Wiguna, Nurmiati Amir, Agung Kusumawardhani

Background. Study to identify the association between zinc serum level and executive function in children with ADHD, that has not been done thoroughly.

Objective. To identify mean differences between serum zinc level in ADHD children with executive dysfunction, without executive dysfunction, and non-ADHD children. Moreover, this study also try to correlate the serum zinc level and the executive function in children with ADHD.

Method. This was a cross-sectional study with control group. Ninety children from two elementary schools in Jakarta were randomly selected. They were categorized into three groups; (1) ADHD children with executive dysfunction group ( $\mathrm{n}=30$ ); (2) ADHD children without executive dysfunction group $(n=30)$, and (3) non-ADHD children group ( $n=30)$. Serum zinc level was analyzed by using ICP-MS method which was done at Prodia Laboratorium in Jakarta. Executive function was examined by using BRIEF-Indonesian version. SPSS 20 for Windows was utilized to analyse the data.

Result. Seventy five percent of research subjects experinced zinc deficiency. Meanwhile, $60 \%$ of children with ADHD suffered from zinc deficiency. There was no significant difference in mean serum zinc level between ADHD children with executive dysfunction group, without executive dysfunction group, and non-ADHD children group $(59.40 \mu \mathrm{g} / \mathrm{dL} \mathrm{vs.} 55.36 \mu \mathrm{g} / \mathrm{dL} \mathrm{vs} .52 .93 \mu \mathrm{g} / \mathrm{dL}$, $\mathrm{p}=0.119)$. The coefficient correlation between zinc serum level and executive function in ADHD children was 0,128 .

Conclusion. Serum zinc level might not be associated directly with executive dysfunction in ADHD children, however it might be related with clinical symptoms of ADHD similar to the executive dysfunction signs and symptoms. Sari Pediatri 2015;17(4):285-91.

Keywords: ADHD, serum zinc, executive function

\footnotetext{
Alamat korespondensi: DR. Dr. Thjin Wiguna, SpKJ. Departemen Psikiatri, Fakultas Kedokteran Universitas Indonesia/Rumah Sakit Umum Pusat Nasional Dr. Cipto Mangunkusumo.Jln Kimia 2/35, Jakarta Pusat 10430. Telepon/Fax 021-310741,021-39899128. E-mail: twiga0o@yahoo.com
} 
G angguan pemusatan perhatian/ hiperaktivitas (GPPH) adalah suatu gangguan neurodevelopmental pada anak. Enampuluh persen anak dengan GPPH akan mengalami gangguan ini sampai dewasa. ${ }^{1}$ Prevalensi GPPH 26,2\% pada anak sekolah di Jakarta. ${ }^{2}$ Anak maupun dewasa yang mengalami GPPH memiliki gejala, antara lain sulit memusatkan perhatian, impulsivitas yang berlebihan, hiperaktif, memiliki masalah menyelesaikan tugas, dan mengganggu orang lain. ${ }^{3}$ Anak dengan GPPH juga dilaporkan mengalami penarikan sosial, perasaan malu, cemas, letargi, kesulitan dalam olahraga dan pembelajaran termasuk membaca dan menulis. ${ }^{4}$

Menurut Barkley, ${ }^{5}$ GPPH merupakan suatu gangguan yang terjadi oleh karena adanya inhibisi perilaku. Inhibisi ini mengakibatkan terjadinya gangguan dalam empat domain fungsi eksekutif yaitu a) gangguan dalam memori kerja, b) gangguan regulasi diri terhadap afek-motivasi-arousal, c) gangguan dalam internalisasi bicara, dan d) gangguan rekonstitusi (analisis dan sintesis perilaku) yang mengakibatkan terjadinya gangguan pengendalian motorik sebagimana yang ditunjukkan dalam gejala GPPH. ${ }^{5}$

Penelitian menunjukkan bahwa gejala GPPH muncul sebagai akibat dari defisit primer pada suatu domain spesifik fungsi eksekutif contohnya inhibisi respons atau memori kerja atau kelemahan umum pada kontrol eksekutif. ${ }^{6}$ Suatu studi potong lintang deskriptif dengan subyek siswa SD dengan GPPH di Jakarta melaporkan bahwa dari 111 anak GPPH ditemukan adanya gangguan fungsi eksekutif pada ranah memori kerja $56,8 \%$, diikuti ranah inhibisi $49,5 \%$ dan pengorganisasian material $46,8 \%{ }^{6}$

Anak dengan GPPH memiliki berbagai gangguan fungsi eksekutif sehingga kualitas pembelajaran rendah terutama yang berkaitan dengan kewaspadaan, pembelajaran verbal, memori kerja, peralihan tugas, perencanaan dan organisasi, penyelesaian masalah kompleks, dan inhibisi respon. ${ }^{7}$ Studi dari Noreika ${ }^{8}$ melaporkan fungsi neurokognitif yang terganggu berupa penggunaan waktu yang tidak efisien dalam hal berbagai tugas yang berkaitan dengan fungsi motorik, persepsi, dan perencanaan. Berdasarkan penelitian dengan pencitraan, gangguan neurokognitif tersebut berhubungan dengan disfungsi pada sirkuit fronto-striato-serebelar dan fronto-parietal. ${ }^{8}$ Secara keseluruhan, gangguan tersebut berhubungan dengan disfungsi eksekutif, khususnya gangguan pada memori kerja, atensi dan kontrol inhibisi. ${ }^{8}$

Sampai saat ini, etiologi GPPH masih belum diketahui dengan pasti dan bersifat kompleks, berkaitan dengan faktor genetik, lingkungan, neurologis, biologis, dan gizi. Salah satu faktor risiko yang diduga berhubungan adalah faktor nutrisi, khususnya zinc atau seng. Uji coba pada anak di Amerika Serikat ditemukan pemberian seng sebagai suplemen dalam makanan menunjukkan adanya perbaikan dalam berbagai tes neuropsikologi yang meliputi fungsi atensi, persepsi, memori, reasoning dan keterampilan motorik. ${ }^{9}$ Pada kasus anak dengan GPPH, hasil penelitian tersebut dikaitkan dengan teori peran seng sebagai inhibitor dopamine transporter yang mirip dengan efek obat stimulan antara lain metilfenidat sehingga memperbaiki gejala klinis GPPH, tetapi dampak terhadap fungsi eksekutif masih belum dapat dipastikan secara tepat. ${ }^{10}$

Dengan demikian, peran seng terhadap perbaikan fungsi eksekutif sudah banyak diteliti, tetapi peran seng terhadap fungsi eksekutif pada anak GPPH masih belum diketahui dengan pasti. Oleh karena itu, penelitian ini dilakukan untuk menjawab pertanyaan apakah anak dengan GPPH yang disertai dengan gangguan fungsi eksekutif mengalami defisiensi seng serum yang lebih berat jika dibandingkan dengan anak GPPH tanpa gangguan fungsi eksekutif maupun anak non-GPPH secara khususnya. Selain itu, penelitian ini juga bertujuan untuk mengidentifikasi korelasi antara kadar seng dalam serum dengan fungsi eksekutif pada anak dengan GPPH.

\section{Metode}

Desain penelitian potong-lintang dengan kelompok kontrol berupa anak GPPH tanpa gangguan fungsi eksekutif dan anak non-GPPH. Penelitian dilaksanakan di SDN 01 dan SDN 02 Kampung Melayu, Jakarta Timur. Pengambilan data dilakukan mulai Mei sampai Juni 2013. Jumlah subjek penelitian 90 anak sekolah dasar yang dibagi tiga kelompok, yaitu 1. kelompok anak GPPH dengan gangguan fungsi eksekutif $(n=30)$; 2. tanpa gangguan fungsi eksekutif $(\mathrm{n}=30)$, dan 3 . non-GPPH $(\mathrm{n}=30)$.

Kriteria inklusi untuk kelompok anak dengan GPPH adalah siswa SD usia 6-12 tahun, laki-laki atau perempuan, tidak menderita penyakit fisik baik akut maupun kronik, tidak didiagnosis retardasi mental, 
tidak menderita gangguan jiwa lainnya selain GPPH, pendidikan orangtua siswa minimal tamat sekolah menengah pertama (SMP), dan orangtua serta siswa bersedia mengikuti penelitian dengan menandatangani surat persetujuan untuk mengikuti penelitian.

Kriteria inklusi untuk anak non-GPPH adalah siswa SD usia 6-12, laki-laki atau perempuan, tidak menderita penyakit fisik baik akut maupun kronik, tidak menderita gangguan jiwa, tidak didiagnosis retardasi mental, pendidikan orangtua siswa minimal tamat sekolah menengah pertama (SMP) dan orangtua serta siswa bersedia mengikuti penelitian.

Pengukuran seng dalam serum dilakukan dengan instrumen analitik inductively coupled plasma atomic emission spectrophotometry dengan memakai sampel darah vena. Pengambilan sampel darah oleh petugas pleibotomi yang sudah terlatih dan proses pengukuran kadar seng dalam serum dilakukan di Laboratorium Prodia.

Nilai normal kadar seng serum yang digunakan dikategorikan menjadi ${ }^{12}$ usia $<10$ tahun, laki-laki dan perempuan, tidak puasa/sewaktu memiliki nilai kadar seng serum $\geq 65 \mathrm{ug} / \mathrm{dL}$. Laki-laki usia $>10$ tahun, tidak puasa/sewaktu memiliki nilai kadar seng serum $\geq 70 \mathrm{ug} /$ dL. Perempuan usia $>10$ tahun, tidak puasa/sewaktu memiliki kadar seng serum $\geq 66 \mathrm{ug} / \mathrm{dL}$.

Abbreviated Conners Parents Rating Scale (ACPRS ${ }^{13}$ ) adalah kuesioner yang telah diterjemahkan dari bahasa Inggris ke bahasa Indonesia pada tahun 1989 di Departemen ilmu Kesehatan Jiwa RSCM - FKUI dengan sensitivitas $100 \%$. Anak dengan nilai ACPRS $\geq 12$ akan diikutsertakan dalam proses wawancara psikiatrik yang berpedoman pada mini-international neuropsychiatric interview-kid (MINI Kid) untuk penentuan diagnosis GPPH.

Coloured Progressive Matrices (CPM) adalah instrumen untuk menilai kemampuan berpikir jernih dan dirancang untuk anak-anak 5-11 tahun. Instrumen ini menggunakan 36 poin dalam tiga set (A, Ab, B) dengan jumlah 12 pertanyaan per set. Tiga set yang tersebut diatur untuk menilai proses kognitif utama yang mudah digunakan oleh anak kecil. Tes ini memiliki penggunaan petunjuk lisan yang mudah dimengerti, dapat digunakan pada tingkat intelegensi yang berbeda-beda, dan dapat dikerjakan oleh individu yang memiliki hendaya seperti bisu, tuli, dan keterbatasan motorik, serta tidak ditemukan adanya biasa budaya. Kecepatan menjawab pertanyaan tidak diperhitungkan. ${ }^{13}$
Behavior Rating Inventory of Executive Function versi Bahasa Indonesia (BRIEF versi Bahasa Indonesia) adalah kuesioner yang terdiri dari 86 butir pertanyaan untuk orangtua dan guru. Penelitian ini menggunakan format untuk orangtua. Kuesioner diisi dengan melingkari salah satu dari tiga huruf yang disediakan pada setiap pertanyaan yaitu huruf $T$ untuk tidak pernah (nilai skor 1), $\mathrm{K}$ untuk kadang-kadang (nilai skor 2), atau $S$ untuk sering sekali (nilai skor 3). Setiap pertanyaan dikelompokkan dalam skala yang ditentukan. Hasil setiap skala dikonversikan menjadi nilai skor T. Nilai T diatas 60 menunjukkan defisit fungsi eksekutif. ${ }^{14}$

Skala Penilaian Perilaku Anak Hiperaktivitas Indonesia (SPPAHI) yang terdiri atas 35 butir pernyataan berisi gejala klinis GPPH yang dapat diisi baik oleh orangtua dan guru dengan memberi tanda pada kolom yang sesuai. Instrumen ini diisi oleh orang tua dengan memberi tanda pada pernyataan-pernyataan mengenai gejala klinis GPPH yang ditemukan pada anak. Nilai batas SPPAHI adalah 29. ${ }^{15}$

Mini-International Neuropsychiatric InterviewKid (MINI Kid) adalah instrumen wawancara terstruktur berdasarkan kriteria diagnostik DSM-IV yang digunakan untuk diagnosis gangguan jiwa pada anak dan remaja. Diagnosis GPPH akan ditegakkan dengan menggunakan instrumen ini. Pengisian kuesioner membutuhkan 15 menit dan didesain untuk memenuhi kebutuhan wawancara psikiatrik untuk uji klinis dan epidemiologi. Pertanyaan wawancara didesain untuk merujuk pada kriteria diagnostik tertentu. Pertanyaan dibacakan secara verbatim. Anak di bawah 13 tahun akan ditemani oleh orang tua dalam menjawab pertanyaan. ${ }^{16}$

Analisis data mengunakan SPPS for Windows versi 20. Protokol penelitian ini mendapatkan surat persetujuan dari Komite Etik Penelitian Kesehatan Fakultas Kedokteran Universitas Indonesia, Rumah Sakit Cipto Mangunkusumo pada tanggal 27 Mei 2013.

\section{Hasil}

Rerata usia subjek penelitian 8,74 tahun dengan proporsi jenis kelamin laki-laki 62\% dari keseluruhan subjek penelitian. Mayoritas dari tiga kelompok subjek penelitian memiliki indek masa tubuh (IMT) normal (73,3\%). Berdasarkan referensi National Health and 
Tabel 1. Karakteristik subjek penelitian $(n=90)$

\begin{tabular}{lc}
\hline Karakteristik & \\
\hline Usia (tahun) & \\
Rerata (SB) & 8,74 (SB 1,38) \\
Rentang & $6-12$ \\
IMT (\%) & \\
Normal & $66(73,3)$ \\
Tidak normal & $24(26,7)$ \\
Seng (ug/dL) (NHNES) & \\
Rerata (SB) & $55,9($ SB 12,28) \\
Rentang & $37-95$ \\
SPPAHI & \\
Rerata & $30,83($ SB 17,52$)$ \\
Rentang & $1-91$ \\
\hline
\end{tabular}

Nutrition Examination Survey (NHNES, Tabel 3), kadar seng serum di bawah normal ditemukan pada 68 anak (65,6\%). Penggunaan referensi NHNES ini berhasil didapatkan 18 anak dengan GPPH yang disertai gangguan fungsi eksekutif mengalami defisiensi seng serum; sedangkan dari kelompok anak dengan GPPH tanpa gangguan fungsi eksekutif dan kelompok anak non-GPPH masing dijumpai 24 anak yang mengalami defisiensi seng serum ( Tabel 1 dan 2).

Usia rerata orangtua (SB), untuk ayah adalah 39,43 (SB 6,37) tahun sedangkan untuk ibu adalah 35,30 (SB 5.63) tahun. Dari karakteristik tingkat pendidikan, pada umumnya lulus SMA/setingkat $(68,9 \%)$ dan mempunyai profil pekerjaan dalam

Tabel 2. Perbedaan karakteristik subjek penelitian masing-masing kelompok

\begin{tabular}{|c|c|c|c|}
\hline Karakteristik & $\begin{array}{l}\text { Anak GPPH dengan } \\
\text { gangguan FE }(n=30)\end{array}$ & $\begin{array}{l}\text { Anak GPPH tanpa } \\
\text { gangguan FE }(n=30)\end{array}$ & $\begin{array}{c}\text { Anak } \\
\text { non-GPPH }(\mathrm{n}=30)\end{array}$ \\
\hline \multicolumn{4}{|l|}{ Usia (tahun) } \\
\hline Rerata (SB) & $8,50(\mathrm{SB} 1,12)$ & $9,00(1,66)$ & 8,73 (SB 1,28) \\
\hline Rentang & $6-12$ & $6-12$ & $6-12$ \\
\hline \multicolumn{4}{|l|}{ IMT (\%) } \\
\hline Normal & $22(73,3)$ & $22(73,3)$ & $22(73,3)$ \\
\hline Tidak normal & $8(26,7)$ & $8(26,7)$ & $8(26,7)$ \\
\hline \multicolumn{4}{|l|}{ Seng (ug/dl) (NHNES) } \\
\hline \multirow[t]{2}{*}{ Rerata (SB) } & 59,40 & 55,36 & 52,93 \\
\hline & (SB 15,05) & $(\mathrm{SB} 11,30)$ & (SB 9,29) \\
\hline Rentang & $38-95$ & $37-80$ & $40-77$ \\
\hline \multicolumn{4}{|l|}{ Usia ayah (tahun) } \\
\hline Rerata (SB) & 38,93 (SB 5,9) & 39,19 (SB 7,83) & $39,72(\mathrm{SB} 5,14)$ \\
\hline Rentang & $29-56$ & $30-62$ & $32-51$ \\
\hline \multicolumn{4}{|l|}{ Usia ibu (tahun) } \\
\hline Rerata (SB) & 34,39 (SB 5,22) & $35,11(5,94)$ & 36,16 (SB 5,62) \\
\hline Rentang & $25-49$ & $27-50$ & $28-45$ \\
\hline \multicolumn{4}{|l|}{ Pendidikan ayah(\%) } \\
\hline Tamat SMP/Setingkat & $6(30,0)$ & $11(55,0)$ & $3(15,0)$ \\
\hline Tamat SMA/Setingkat & $21(33,9)$ & $17(27,4)$ & $24(38,7)$ \\
\hline $\mathrm{D} 1 / \mathrm{D} 3 / \mathrm{S} 1$ & $3(37,5)$ & $2(25,0)$ & $3(37,5)$ \\
\hline \multicolumn{4}{|l|}{ Pekerjaan orangtua (\%) } \\
\hline Pegawai negeri/ABRI & $0(0,0)$ & $0(0,0)$ & $1(100,0)$ \\
\hline Pegawai swasta & $17(34,0)$ & $16(32,0)$ & $17(34,0)$ \\
\hline Dagang & $3(30,0)$ & $3(30,0)$ & $4(40,0)$ \\
\hline Tidak bekerja & $0(0,0)$ & $1(50,0)$ & $1(50,0)$ \\
\hline Lain-lain & $10(37,0)$ & $10(37,0)$ & $7(25,9)$ \\
\hline \multicolumn{4}{|c|}{ Status ekonomi orangtua, Rp, n (\%) } \\
\hline$<618.750$ & $2(100,0)$ & $0(0,0)$ & $0(0,00)$ \\
\hline $618.750-7.548 .750$ & $26(30,2)$ & $30(34,9)$ & $30(34,9)$ \\
\hline$>7.548 .750$ & $2(100,0)$ & $0(0,0)$ & $0(0,0)$ \\
\hline
\end{tabular}


sektor swastaKarakteristik status ekonomi orang tua menunjukkan kelompok terbesar ada pada kategori dengan pendapatan antara Rp. 618.750 sampai dengan Rp. 7.548.750 (Tabel 2).

Hasil pemeriksaan seng serum menunjukkan 18 anak GPPH dengan gangguan fungsi eksekutif memiliki kadar seng tidak normal dengan rerata serum seng 49,1 ug/dL, sedangkan pada kelompok anak GPPH tanpa gangguan fungsi eksekutif 24 anak memiliki kadar seng tidak normal dengan rerata serum seng 50,47 ug/dL dan pada kelompok non-GPPH 26 anak memiliki kadar seng tidak normal dengan rerata serum seng 52,93 ug/dL. Dari hasil pemeriksaan SPAHI, kelompok anak GPPH dengan gangguan fungsi eksekutif didapatkan rerata nilai SPPAHI sebesar 40 dan kelompok anak GPPH tanpa gangguan fungsi eksekutif didapatkan rerata nilai 39. Pada kelompok anak non-GPPH ditemukan rerata skor SPPAHI 13.

Rerata seng serum ketiga kelompok tersebut tidak menunjukkan perbedaan yang bermakna secara statistik $(\mathrm{p}=0,175)$. Dari hasil uji korelasi Spearman diperoleh koefisien korelasi antara kadar seng serum dengan nilai BRIEF pada anak dengan GPPH 0,128. Di lain pihak, koefisien korelasi antara kadar seng dalam serum dengan fungsi eksekutif -0,104, tetapi koefisien korelasi antara kadar seng dalam serum 0,307.

\section{Pembahasan}

Kami mendapatkan proporsi $75 \%$ anak yang mengalami defisiensi seng dari 90 subjek penelitian. Hal tersebut tidak mengherankan berdasarkan dengan penelitian yang sudah dilakukan di Grobogan, Jawa Tengah yang melaporkan bahwa $40 \%$ anak mengalami defisiensi seng. Sementara itu, laporan penelitian di Solo juga melaporkan bahwa $100 \%$ anak dari 10 sekolah dasar mengalami defisiensi seng. ${ }^{17}$ Kondisi tersebut menunjukkan bahwa pola makanan anak yang ikut serta dalam penelitian mungkin masih belum memenuhi standar kebutuhan seng seperti yang tercantum dalam angka kebutuhan seng bagi anak di Indonesia.

Hasil penelitian ini menunjukkan bahwa ada perbedaan antara rerata kadar seng dalam serum pada anak GPPH dengan gangguan fungsi eksekutif, anak GPPH tanpa gangguan fungsi eksekutif dan anak nonGPPH, tetapi tidak bermakna secara statistik. Namun, hal yang menarik adalah rerata kadar seng dalam serum pada kelompok anak GPPH dengan gangguan fungsi eksekutif ternyata lebih tinggi jika dibandingkan dengan ke dua kelompok lainnya. Disamping itu, dari ketiga kelompok dalam penelitian kami, proporsi anak GPPH dengan gangguan fungsi eksekutif yang disertai juga dengan kadar seng dalam serum di bawah normal ternyata juga lebih kecil. Hasil penelitian ini menunjukkan bahwa seng dalam serum mungkin tidak dapat dijadikan parameter langsung dengan terjadinya gangguan fungsi eksekutif pada anak dengan GPPH, tetapi lebih sesuai jika dikaitkan dengan perburukan gejala klinis GPPH yang ada.

Secara teoritis, kadar seng dalam tubuh seringkali dikaitkan dengan peran regulasi transporter dopamin. Seng tersebut dilaporkan sebagai penghambat fungsi transporter dopamin yang meningkat aktivitasnya melalui perlekatannya pada sisi luar transporter dopamin tersebut. Pada anak yang mengalami defisiensi seng peran sebagai penghambat tersebut mengalami kegagalan sehingga menyebabkan terjadinya peningkatan fungsi transporter dopamin yang berakibat timbulnya gejala GPPH. ${ }^{18}$

Pada anak dengan GPPH, adanya defisiensi seng dalam serum lebih memperberat penurunan kadar neurotransmitter dopamin di celah sinaps di daerah striatal, yaitu melalui dis-inhibisi (akselerasi) dopamin ke dalam intrasel melalui proses translokasi dan inhibisi (deselerasi) efflux dopamin. Suplementasi seng dilaporkan dapat memperbaiki aktivitas transporter dopamin dan selanjutnya dapat meningkatkan jumlah neurotransmitter dopamin di celah sinaps sehingga dikatakan mengurangi gejala GPPH yang ada. ${ }^{18}$

Apakah gangguan fungsi eksekutif pada anak dengan GPPH sebenarnya merupakan bagian dari gejala klinis GPPH? Berdasarkan teori yang dikemukakan oleh Barkley, ${ }^{19}$ gejala klinis GPPH terdiri dari defisit pada inhibisi perilaku. Inhibisi dihubungkan dengan disfungsi pada empat domain fungsi eksekutif, yaitu a) memori kerja, antara lain mempertahankan kejadiankejadian dalam pikiran (contoh gejala di antaranya sulit mempertahankan detil atau melakukan kecerobohan dalam tugas, sulit mempertahankan perhatian, mudah teralih perhatiannya), b) regulasi diri terhadap afekmotivasi-arousal, antara lain regulasi terhadap aksi yang bertujuan (contoh: selalu bergerak, tidak bisa duduk diam), c) internalisasi bicara (contoh: tidak mengikuti instruksi dan menyelesaikan tugas), dan d) rekonstitusi antara lain analisis dan sintesis perilaku (contoh: sering 
menjawab sebelum pertanyaan diajukan, menginterupsi atau menyela orang lain). Semua gejala tersebut tumpang tindih dengan gejala klinis GPPH. Hal tersebut ditunjukkan dalam analisis uji korelasi antara kadar seng dalam serum dengan fungsi eksekutif pada anak dengan GPPH yang menunjukkan korelasi lemah. Hasil penelitian ini menyerupai hasil penelitan yang dilakukan di Turki pada anak GPPH dengan menggunakan uji sinyal bioelektrik, yaitu adanya pengaruh kadar seng dalam serum terhadap salah satu domain fungsi eksekutif yaitu proses informasi. ${ }^{20}$

Hasil tersebut menunjukkan bahwa seng mungkin saja berperan terhadap terjadinya gangguan fungsi eksekutif, tetapi tidak terbukti pada anak dengan GPPH. Dengan demikian, seng bukanlah satu-satunya faktor yang menyebabkan terjadinya gangguan fungsi eksekutif pada anak dengan GPPH. Masih ada faktor lainnya yang tidak diteliti dalam penelitian ini seperti faktor genetik, stimulasi dini, dan juga pola makanan. Dalam suatu systematic review yang diterbitkan dalam European journal of clinical nutrition pada tahun 2015 menjelaskan bahwa ada pengaruh seng terhadap fungsi kognitif yaitu terhadap fungsi eksekutif dan keterampilan motorik, tetapi tidak bermakna secara statistik. $^{21}$

Penelitian kami memiliki beberapa keterbatasan, yaitu tidak melibatkan beberapa faktor yang sudah disebutkan di atas, serta kemungkinan adanya bias pengukuran BRIEF versi Indonesia dilakukan langsung oleh orangtua masih mungkin terjadi walaupun orangtua sudah memahami cara pengisian sesuai intruksi yang diberikan. Selain itu, tidak dilakukan penelusuran pola makan anak dan variasi diurnal yang mungkin dapat memengaruhi kadar seng serum. Namun, penelitian ini adalah penelitian pertama di Indonesia yang berusaha untuk mencari hubungan antara kadar seng dalam serum dengan fungsi eksekutif pada anak dengan GPPH sehingga dapat dijadikan sebagai acuan untuk melakukan penelitian serupa di kemudian hari dengan desain yang lebih baik.

\section{Daftar pustaka}

1. Young GS, Maharaj NJ, Conquer JA. Blood phospholipid fatty acid analysis of adults with and without attention deficit/hyperactivity disorder. Lipids 2004;39:117-23.

2. Suryani E. Gambaran fungsi eksekutif pada anak sekolah dasar dengan gangguan pemusatan perhatian/ hiperaktivitas (GPPH) di wilayah DKI Jakarta (tesis). Jakarta: Universitas Indonesia Fakultas Kedokteran/ Rumah Sakit Cipto Mangunkusumo, 2011.

3. Ross BM, Seguin J, Sieswerda LE. Omega-3 fatty acids as treatments for mental illness: which disorder and which fatty acid? Lipids Health Dis 2007;6:21.

4. Doggett AM. ADHD and drug therapy: is it still a valid treatment? J Child Health Care 2004;8:69-81.

5. Barkley RA. Behavioral inhibition, sustained attention, and executive functions: Constructing a unigying theory of ADHD. Psychol Bull 1997:121;65-94.

6. Erik GW, Alysa ED, Joel TN, Stephen VF, and Bruce FP. Validity of the executive function theory of AttentionDeficit/Hyperactivity Disorder: A Meta-Analytic Review. Biol Psychiatry 2005;57:1336-46.

7. Seidman LJ. Neuropsychological functioning in people with ADHD across the lifespan. Clin Psychol Rev 2006:26;466-485Krause J. SPECT and PET of the dopamine transporter in attention-deficit/hyperactivity disorder. Expert Rev Neurother 2008;8:611-25.

8. Noreika V, Falter CM, Rubia K. Timing deficits in attention-deficit/hyperactivity disorder (ADHD): Evidence from neurocognitive and neuroimaging studies. Neuropsychologia 2013;51:235-66.

9. Black MM. The evidence linking zinc deficiency with children's cognitive and motor functioning. J Nutr 2003:133;1473S-6S.

11. Krause J. SPECT and PET of the dopamine transporter in attention-deficit/hyperactivity disorder. Expert Rev Neurother 2008; 8:611-25.

11. Hotz C, Peerson JM, Brown KH. Suggested lower cutoffs of serum zinc concentration for assessing zinc status: reanalysis of the second national health dan nutrition examination survey data (1976-1980). Am J Clin Nutr 2003;78:756-64.

12. Yuniar S. Penentuan validitas dan reliabilitas abbreviated Conners' teacher rating scale sebagai penyaring gangguan pemusatan perhatian/hiperaktivitas (Tesis). Jakarta: Departamen Psikiatri Fakultas Kedokteran Universitas Indonesia, 1989.

13. Pearson Education. Texas: Pearson Education 2012. Diakses pada 11 April 2013. Didapat dari: http://www. pearsonassessments.com/HAIWEB/Cultures/en-us/Productdetail. htm?Pid=015-4686-7436Mode=summary.

14. Riyadi EI, Wiguna T, Irmansyah. Behavior rating inventory of executive function versi Bahasa Indonesia (BRIEF-BI). Petunjuk penggunaan untuk profesional. Jakarta: Departemen Psikiatri FKUI - RSCM; 2009.

15. Saputro D. ADHD, Attention deficit/hyperactivity 
disorder. Edisi pertama. Jakarta: Sagung Seto;2009.

16. Sheehan DV, Lecrubier Y, Sheehan H, Amorim P, Janavs J, Weiller E, dkk. The mini-international neuropsychiatric interview (M.I.N.I): the development and validation of a structured diagnostic psychiatric interview for DSM-IV and ICD-10. J Clin Psychiatry 1998;59:22-33.

17. Putra SE. Anak Indonesia kekurangan zat besi dan seng. Diakses pada 11 Agustus 2015. Didapat dari: http:// www.sinlyevanputra6.wordpress.com/2012/12/29/anakindonesia-kekurangan-zat-besi-dan-seng.

18. Lepping F, and Hubet M. Role of zinc in the pathogenesis of attention deficit hyperactivity disorder implications for research and treatment. CNS Drugs 2010;2:721-72.

19. Barkley RA. Behavioral inhibition, sustained attention, and executive functions: Constructing a unigying theory of ADHD. Psychological Bulletin 1997;121;65-94.

20. Yorbik O, Ozdag MF, Olgun A, Senol MG, Bek S, Akman S. Potential effects of zinc on information processing in boys with attention deficit hyperactivity disorder. Prog in neuro-psychoph 2008;32:662-7.

21. Warthon-Medina M, Moran VH, Stammers AL, Dillon S, Qualter P, Nissensohn M, dkk. Zinc intake, status and indices of cognitive function in adults and children: a systematic review and meta analysis. Eur J Clin Nutr 2015;69:649-61. 